\title{
KARAKTERISTIK BRIKET YANG DIBUAT DARI KULIT DURIAN DAN PEREKAT PATI JANENG
}

\author{
Irhamni ${ }^{1}$, Saudah $^{1}$, Diana $^{1}$, Ernilasari $^{1}$, Mulia Aria Suzanni ${ }^{2}$, dan Israwati $^{1}$ \\ 1) Universitas Serambi Mekkah, Banda Aceh \\ Jl. T.Imum Lueng Bata, Batoh, Banda Aceh \\ 2) Akademi Analis Farmasi dan Makanan \\ Teuku Cik Ditiro Gedung Graha Ilon No.15 Peuniti Kota Banda Aceh \\ E-mail : irhamni@serambimekkah.ac.id
}

Received : 29 Mei 2018; revised : 20 September 2018; accepted : 8 April 2019

\begin{abstract}
ABSTRAK
KARAKTERISTIK BRIKET YANG DIBUAT DARI KULIT DURIAN DAN PEREKAT PATI JANENG. Limbah kulit durian merupakan salah satu bahan baku yang dapat diolah menjadi energi alternatif pengganti bahan bakar. Beberapa jenis limbah biomassa memiliki potensi yang cukup besar seperti limbah kayu, sekam padi, jerami, ampas tebu, cangkang sawit, dan sampah kota. Potensi lain yang belum tergarap adalah limbah kulit durian. Limbah-limbah tersebut apabila tidak dimanfaatkan akan menimbulkan bau yang tidak sedap dan dapat merusak ekosistem lingkungan. Penelitian ini bertujuan untuk melihat karakteristik pembakaran briket dari kulit durian berdasarkan nilai kalor dan uji nyala. Pembuatan briket ini menggunakan bahan perekat pati janeng sebanyak 1:2 dari berat briket, ukuran partikel briket adalah 80 mesh, bentuk briket lempeng dan silinder. Hasil penelitian menunjukkan bahwa briket yang dihasilkan telah memenuhi standar bahan bakar untuk rumah tangga. Nilai kalor yang dihasilkan oleh briket kulit durian adalah $5040 \mathrm{kal} / \mathrm{gram}$, waktu yang dibutuhkan briket untuk menyala adalah 10 menit, dan lamanya nyala api pada briket adalah 55 menit tanpa menghasilkan asap diawal pembakaran. Briket yang paling baik dihasilkan adalah briket dengan ukuran 80 mesh berbentuk lempeng bulat dan nilai kalor $5040 \mathrm{kal} / \mathrm{gram}$. Dapat disimpulkan bahwa briket yang dihasilkan dari limbah kulit durian dengan menggunakan pati janeng dapat digunakan sebagai bahan bakar alternatif yang ramah lingkungan.
\end{abstract}

Kata kunci : Limbah kulit durian, Briket, Uji nyala

\section{ABSTRACT}

CHARACTERISTICS OF BRIQUETTES MADE FROM DURING SKIN AND ADHESIVE JANENG STARCH. Durian skin is one of the raw materials that can be processed into alternative energy. Some types of biomass waste have considerable potentials such as wood waste, rice husks, straw, bagasse, palm shells, and municipal waste. Another untapped potential is waste from durian skins. If these wastes are not utilized, they will cause unpleasant odors and can damage the ecosystem of the environment. This study aims to look at the characteristics of burning briquettes from durian skin based on calorific value and flame test. In the work, the making of this briquette was by using 1:2 janeng starch adhesive from the weight of the briquette. The particle size of the briquette was 80 mesh with the shape of plate and cylinder. The results of characterization showed that the briquettes have met the fuel standards for households. The calorific value produced by durian skin briquettes was $5040 \mathrm{cal} / \mathrm{gram}$. The time needed for briquettes to light was 10 minutes and the duration of the flame on the briquette was 55 minutes without producing smoke at the beginning of combustion. The best briquettes produced were 80 mesh briquettes in the shape of a round plate and a heating value of $5040 \mathrm{cal} / \mathrm{gram}$. It can be concluded that the briquettes produced from the waste of durian skin using janeng starch can be used as an environmentally friendly alternative fuel.

Keywords : Durian skin, Briquettes, Flame test

\section{PENDAHULUAN}

Biomassa adalah suatu limbah padat yang bisa dimanfaatkan kembali sebagai sumber bahan bakar (Yokoyama 2008). Salah satu upaya dalam rangka penyediaan energi alternatif adalah dengan memanfaatkan limbah organik sebagai bahan baku. Salah satu jenis potensi biomassa yang belum tergarap adalah limbah kulit durian. Limbah tersebut apabila tidak dimanfaatkan akan menimbulkan bau yang tidak sedap dan dapat merusak ekosistem lingkungan. Pembuatan energi alternatif relatif mudah. Limbah organik yang digunakan sebagai 
bahan baku adalah Durio zibethinus Murray atau durian. Limbah dapat menyebabkan pencemaran lingkungan, munculnya penyakit dan menurunkan nilai estetika atau keindahan kota serta masalah-masalah lainnya. Kandungan karbohidrat pada kulit durian cukup tinggi. Serat kulit durian merupakan limbah dari buah durian. Kandungan serat kulit durian dari buah durian adalah sekitar $60 \%$ sampai $75 \%$. kulit durian terdiri dari oflignin (15,45\%), hemiselulosa $(13,09 \%)$ dan selulosa $(60,45 \%)$ (Aimi et al. 2014)

Limbah pertanian yang berasal dari biomassa yang merupakan sumber energi alternatif yang melimpah dengan kandungan energi yang relatif besar sehingga dapat diolah menjadi suatu bahan bakar padat buatan sebagai bahan bakat alternatif yang disebut dengan briket (Wilasita dan Purwaningsih 2014).

Penelitian diseluruh dunia telah melaporkan ada berbagai metode pembuatan briket dari limbah pertanian sebagai sumber energi yang dapat diandalkan (Shekhar 2011). Teknologi pembuatan briket umumnya menggunakan pemadatan tekanan tinggi, pemadatan tekanan sedang (dibantu oleh pemanasan perangkat yang digunakan) dan pemadatan tekanan rendah tanpa perekat. Kerapatan biomassa limbah pertanian tergantung pada beberapa faktor, seperti jenis perekat yang digunakan, kelembaban, ukuran partikel, indeks pecah, serat, kualitas lignin), kepadatan dan suhu pemadatan serta tekanan. Tekanan pemadatan merupakan salah satu parameter yang paling penting yang mempengaruhi kualitas briket dari biomassa (Grover, Mishra, and Clancy 1994).

Teknologi pembuatan biobriket telah banyak dilakukan oleh peneliti sebelumnya dengan mengkomposisi berbagai macam bahan baku yang berasal dari bahan-bahan organik dan limbah pertanian. Hasil penelitian terhadap biobriket dari limbah cangkang kakao dengan menggunakan tepung kanji sebagai perekat yang dilakukan oleh Munas et al. (2012) dengan variasi ukuran partikel biobriket adalah 30 mesh dan 60 mesh, bentuk biobriket silinder berongga dan silinder pejal. Biobriket yang paling bagus adalah biobriket dengan ukuran 30 mesh silinder berongga dan nilai kalor yang dihasilkan adalah lebih besar dari 4000 kal/gram. Peneliti lain, Syamsiro dan Saptoadi (2007) dalam penelitian terhadap biobriket bahan baku dari cangkang kakao dengan melihat pengaruh temperatur preheat terhadap laju pembakaran biobriket. Ukuran partikel merupakan faktor yang mempengaruhi proses pembuatan biobriket dimana semakin kecil ukuran partikel semakin kuat briket yang dihasilkan namun porositasnya semakin rendah dan sebaliknya.
Penelitian sebelumnya yang telah dilakukan oleh Shuma dan Madyira (2017) produksi briket dari limbah pertanian dan residu hutan dengan menggunakan berbagai metode, prosedur dan proses produksi briket. Perekat yang digunakan adalah kotoran sapi dan tumbuhan kaktus. Proporsi perekat yang digunakan adalah sebesar $86 \%$, merupakan proporsi optimal untuk perekat. Limbah pertanian dan residu hutan diperoleh dari provinsi Limpopo, Afrika Selatan. Parameter yang diuji adalah kandungan energi, kadar air dan ukuran partikel dari briket. Briket dibentuk dan dipadatkan menggunakan hidrolik pada tekanan $6 \mathrm{Mpa}, 4 \mathrm{Mpa}, 12 \mathrm{Mpa}, 7 \mathrm{Mpa}$, dan 19 Mpa. Parameter optimum briket diperoleh pada tekanan 19 Mpa dengan rasio perekat 35:65. Briket dari campuran daun moponi, kulit kacang tanah, dan daun tebu menggunakan gabungan perekat kotoran sapi dan tumbuhan kaktus menghasilkan briket kualitas baik dibandingkan dengan briket dari rumput kuning.

Penelitian lain yang dilakukan oleh Nuriana et al. (2014) mengembangkan dan menguji karakteristik briket kulit durian sebagai bahan bakar dengan menerapkan analisis proksimat. Suhu karbonisasi $450^{\circ} \mathrm{C}$, fixed carbon ( $F C$ ) yang diperoleh adalah sebesar $77,87 \%$, kelembaban $0,01 \%$, volatile matter 3,94\%, kadar abu $18,18 \%$, kadar air $0,09 \% \mathrm{~g} / \mathrm{mL}$, nilai kalor $6274,29 \mathrm{kkal} / \mathrm{kg}$, kuat tekan 15,10 N/cm. Ukuran briket 100 mesh dengan diameter briket $3,8 \mathrm{~cm}$, tinggi $6,5 \mathrm{~cm}$. Proses densifikasi atau karbonisasi briket menaikkan nilai kalor per volume. Sari et al. (2015) membuat briket dari kulit durian dan campuran biomassa lain, seperti cangkang sawit dan cangkang karet dengan rasio 2:1 dan 3:1. Jenis perekat yang digunakan adalah biji nangka dan tepung tapioka. Bentuk cetakan briket adalah silinder dan ellipsoidal menggunakan cetakan manual. Briket bentuk silinder dari campuran kulit durian dan cangkang karet dengan rasio 3:1 dan briket bentuk ellipsoidal dengan rasio 2:1 menggunakan perekat tapioka, kuat tekan yang diperoleh adalah sebesar $19,457 \mathrm{~g} / \mathrm{cm}^{2}$ dan $25,593 \mathrm{~g} / \mathrm{cm}^{2}$, lama waktu penyalaan 2064 detik dan 4121 detik. Nilai kalor briket yang dihasilkan adalah sebesar $5219 \mathrm{kal} / \mathrm{g}$ dan $5151 \mathrm{kal} / \mathrm{g}$ dan mencapai nilai standar kalor berdasarkan SNI (5000 kal/g).

Penelitian ini bertujuan untuk melihat karakteristik pembakaran briket dari limbah kulit durian dengan menggunakan pati janeng sebagai perekat yang meliputi nilai kalor, dan kualitas uji nyala briket yang dihasilkan, dan dapat digunakan sebagai bahan bakar alternatif yang ramah lingkungan. 


\section{BAHAN DAN METODE}

\section{Bahan}

Bahan pembuatan briket adalah limbah kulit durian, pati janeng sebagai perekat dan air panas. Pemilihan pati janeng sebagai perekat karena mengandung sekitar $20 \%$ amilosa dan $80 \%$ amilopektin, berpotensi menjadi perekat yang baik, kemurnian larutannya tinggi, kekuatan gel yang baik dan daya rekat yang tinggi.

Peralatan yang di gunakan adalah pisau, parang, ayakan mesh, gelas ukur, pengaduk, hot plate, baskom, cetakan briket, oven, bomb calorimeter, furnace, desikator.

\section{Metode}

Pembuatan briket limbah kulit durian dapat dilakukan dengan menggunakan metode karbonisasi. Pembuatan briket diawali dengan persiapan bahan baku limbah kulit durian, membuat larutan perekat pati janeng dan pembuatan briket.

Prosedur penelitian meliputi, persiapan bahan baku, persiapan bahan perekat, dan pembuatan briket.

1. Persiapan bahan baku

Pada proses ini, bahan baku dipotong menjadi ukuran kecil, kemudian dikeringkan di bawah sinar matahari sampai kadar air $12 \%$, dan selanjutnya dikarbonisasikan pada suhu $400{ }^{\circ} \mathrm{C}$.

2. Persiapan perekat pati janeng

Umbi janeng dicuci bersih untuk menghilangkan racun sianida, kemudian dipotong dadu dan di blender dengan penambahan aquadest $100 \mathrm{ml}$. Bubur janeng kemudian dipanaskan hingga mengental.

3. Pembuatan briket

Arang kulit durian yang sudah disaring kemudian dicampurkan dengan perekat pati janeng dan ditambahkan sedikit air sambil diaduk rata hingga menggumpal. Selanjutnya adonan dimasukkan kedalam cetakan dan dikering dalam oven pada suhu $60^{\circ} \mathrm{C}$.

Variabel proses dalam penelitian ini akan dianalisis mutu briket berupa nilai kalor, kadar abu, karbon tetap (fixed carbon), zat terbang, kuat tekan dan uji nyala, sehingga variabel tersebut mempengaruhi karakteristik briket yang layak berdasarkan SNI.

\section{Analisa Mutu}

Nilai Kalor

Nilai kalor dapat ditentukan dengan membakar sejumlah contoh dalam bomb calorimeter pada kondisi standar. Kalor yang dihasilkan dapat dihitung dari perubahan temperatur sebelum dan sesudah pembakaran dengan mengadakan beberapa koreksi.

$$
N \quad k \quad=\frac{N(\mathrm{I}-\mathrm{I})-\mathrm{B}}{\mathrm{b}} \text { Kalori } / \mathrm{gr}
$$

Na menyatakan nilai air kalorimeter yakni 2459 kalori; $\mathrm{T}_{\mathrm{a}}$ menyatakan temperatur akhir vessel; $T_{0}$ temperatur awal vessel; $\mathrm{B}$ jumlah nilai koreksi dari $\mathrm{HNO}, \mathrm{H}_{2} \mathrm{SO}_{4}$, dan kawat $\mathrm{Ni}-\mathrm{Cr}$.

\section{Uji Nyala}

Uji nyala dapat ditentukan dengan waktu penyalaan (menit), lama nyala api (menit), kestabilan nyala dan asap awal pembakaran.

\section{HASIL DAN PEMBAHASAN}

Briket yang dihasilkan pada penelitian adalah jenis silinder. Bentuk briket dapat dilihat pada Gambar 1. Briket yang berbentuk silinder kebanyakan digunakan untuk kalangan industri kecil dan menengah. Data hasil pengamatan dapat dilihat pada Tabel 1. Standar mutu dan karakteristik pembuatan briket untuk rumah tangga di Indonesia dapat dilihat pada Tabel 2.
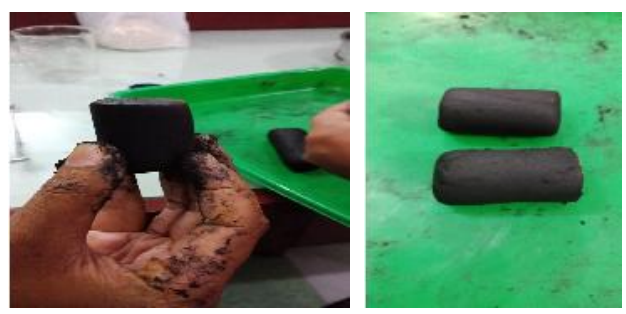

Gambar 1. Briket kulit durian

Tabel 1. Hasil pengamatan jenis briket

\begin{tabular}{lcccc}
\hline \multirow{2}{*}{ Jenis briket } & \multicolumn{3}{c}{ Parameter hasil } \\
\cline { 2 - 5 } & $\begin{array}{c}\text { Kadar air } \\
(\%)\end{array}$ & $\begin{array}{c}\text { Kadar abu } \\
(\%)\end{array}$ & $\begin{array}{c}\text { Zat terbang } \\
(\%)\end{array}$ & $\begin{array}{c}\text { Nilai kalor } \\
\text { kal/gram }\end{array}$ \\
\hline A1 (Arang) & 1,8 & 6,8 & 5 & 5460 \\
B1(Briket) & 1,3 & 7,7 & 6 & 5040 \\
Standar mutu & Max. 8 & Max. 8 & 15 & Min. 5000 kal/gram \\
\hline
\end{tabular}




\section{Nilai Kalor}

Nilai kalor yang dihasilkan pada penelitian briket kulit durian dengan pati janeng sebagai perekat (Tabel 1) secara umum telah memenuhi spesifikasi bahan bakar untuk skala rumah tangga (> $5.000 \mathrm{kal} / \mathrm{gram}$ ).

Nilai kalor yang terbesar terdapat pada jenis arang ukuran 100 mesh silinder berongga sebesar $5460 \mathrm{kal} / \mathrm{gram}$, sedangkan nilai kalor yang lebih kecil adalah biobriket limbah kulit durian ukuran 80 mesh silinder tanpa rongga sebesar $5040 \mathrm{kal} / \mathrm{gram}$. Berdasarkan Pramana dan Pradana (2010) nilai kalor ini dipengaruhi oleh kadar air, semakin rendah kadar air dalam biobriket maka nilai kalor yang diperoleh semakin besar. Untuk biobriket memiliki kadar air terendah karena memiliki rongga dan berukuran partikel lebih besar, sehingga pada saat proses pengeringan kadar air dalam biobriket lebih mudah menguap. Faktor lain yang mempengaruhi nilai kalor adalah komposisi biobriket, namun penelitian ini tidak divariasikan komposisi biobriket.

\section{Uji Nyala}

Tabel 3 menunjukkan waktu penyalaan api jenis arang dan briket berturut-turut adalah 7 menit dan 10 menit. Sementara nyala api pada jenis briket lebih lama dibandingkan pada jenis arang yaitu 55 menit, semakin lama nyala api maka semakin bagus kualitas dari biobriket. Pada biobriket tidak adanya asap pada awal pembakaran, hal tersebut menunjukkan bahwa kualitas biobriket dari limbah kulit durian sangat baik dibandingkan dengan arang.

Gambar $3 \mathrm{~A}_{a}$ menunjukkan jenis arang. Waktu yang dibutuhkan untuk menyalakan api pada arang agar terbakar adalah 7 menit, lamanya nyala api 40 menit, kestabilan nyala api yang dihasilkan oleh arang tidak stabil dan diawal pembakaran arang sudah menghasilkan asap. Gambar $3 A_{b}$ menjelaskan bahwa waktu yang dibutuhkan briket agar terbakar adalah 10 menit dan lamanya nyala api pada briket adalah 55 menit (gambar 3B). Hal ini menunjukkan bahwa lamanya nyala api pada briket lebih lama dibandingkan dengan lamanya nyala api pada arang. Lamanya nyala api berpengaruh terhadap kualitas biobriket yang dihasilkan, semakin lama nyala api maka semakin baik biobriket yang dihasilkan. Kestabilan nyala api yang dihasilkan oleh briket tidak stabil. Diawal pembakaran, biobriket dari limbah kulit durian tidak menghasilkan asap dan ramah lingkungan, sehingga biobriket limbah kulit durian lebih unggul dibandingkan dengan jenis arang.

Gambar 3C abu yang dihasilkan dari uji nyala selama penyalaan berwarna keabuan dan sangat halus, menandakan kualitas kadar abu sesuai dengan Standar Baku Mutu SNI. Dari awal penyalaan hingga menjadi abu, biobriket dari limbah kulit durian dengan menggunakan perekat pati janeng tidak menghasilkan asap pembakaran. Sehingga biobriket ini layak dijadikan sebagai bahan bakar alternatif terbarukan yang ramah lingkungan.

Tabel 2. Standar mutu dan karakteristik briket (SNI 01-6235 (2000))

\begin{tabular}{ccc}
\hline No & Parameter & Nilai \\
\hline 1 & Kadar air & $8 \%$ \\
2 & Kadar abu & $8 \%$ \\
3 & Kadar Zat terbang & $15 \%$ \\
4 & Kadar belerang & $<1 \%$ \\
5 & Nilai kalor & Min. $5000 \mathrm{kal} / \mathrm{gram}$ \\
6 & Kuat tekan & $>25 \mathrm{~kg} / \mathrm{cm}^{2}$ \\
7 & Karbon terikat & Min. 69 \\
\hline
\end{tabular}

Tabel. 3. Karakteristik pembakaran briket yang dihasilkan

\begin{tabular}{lcccc}
\hline Perlakuan & & Uji nyala & Asap awal pembakaran \\
\cline { 2 - 4 } & $\begin{array}{c}\text { Waktu penyalaan } \\
\text { (menit) }\end{array}$ & $\begin{array}{c}\text { Lama nyala api } \\
\text { (menit) }\end{array}$ & Kestabilan nyala & Ada \\
Arang & 7 & 40 & Tidak stabil & Tidak ada
\end{tabular}



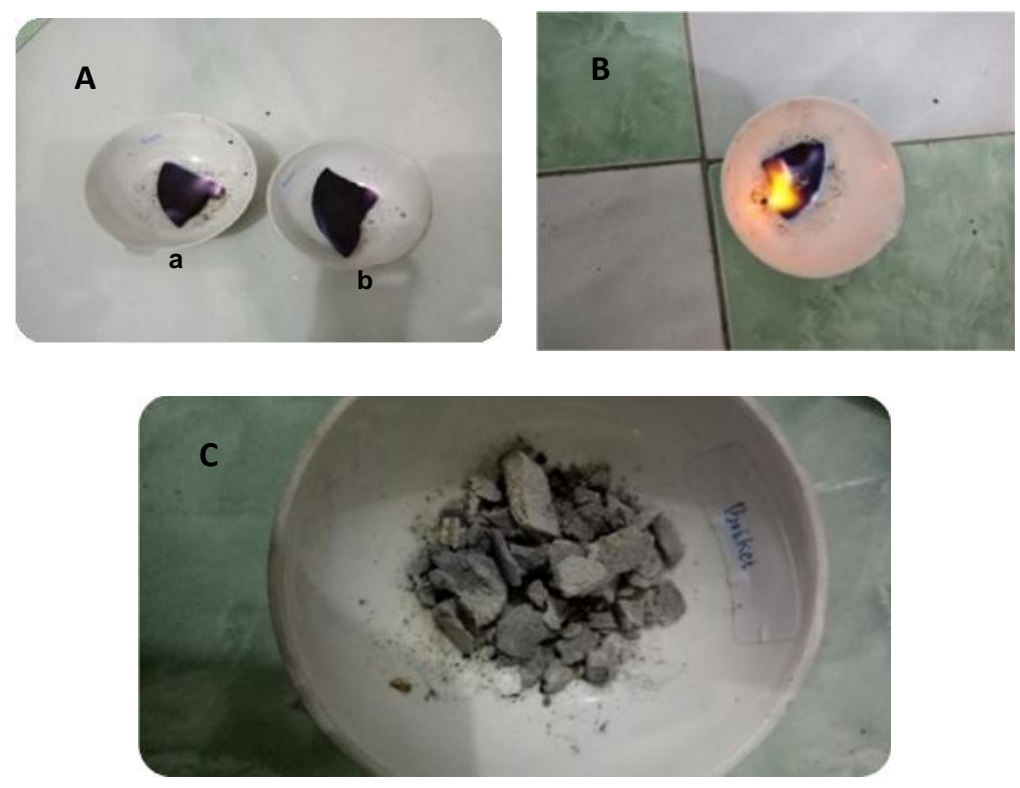
Ket :

Gambar $3 A_{a}$

Gambar $3 A_{b}$

Gambar 3B

Gambar C
: Arang

: Biobriket

: Abu yang dihasilkan dari pembakaran

\section{KESIMPULAN}

Nilai kalor yang di hasilkan pada penelitian briket kulit durian dengan pati janeng sebagai perekat secara umum telah memenuhi spesifikasi bahan bakar untuk skala rumah tangga (> $5.000 \mathrm{kal} / \mathrm{gram}$ ), nilai kalor yang paling kecil untuk briket limbah kulit durian ukuran 80 mesh silinder tanpa rongga sebesar $5040 \mathrm{kal} / \mathrm{gram}$. Nyala api pada jenis briket lebih lama dibandingkan pada jenis arang yaitu 55 menit, semakin lama nyala api maka semakin bagus kualitas dari briket. Pada briket tidak adanya asap pada awal pembakaran, hal tersebut menunjukkan bahwa kualitas briket dari limbah kulit durian lebih bagus dibandingkan dengan arang.

\section{UCAPAN TERIMAKASIH}

Peneliti mengucapkan terimakasih banyak kepada Kemenristekdikti atas bantuan dana hibah Penelitian Terapan Unggulan Perguruan Tinggi (PTUPT) dan Universitas Serambi Mekkah serta LPPM USM yang memfasilitasi penelitian ini.

\section{DAFTAR PUSTAKA}

Aimi, N. Nur, H. Anuar, M.R. Manshor, W.B. Wan Nazri, and S.M. Sapuan. 2014. "Optimizing the Parameters in Durian Skin Fiber Reinforced Polypropylene Composites by Response Surface
Methodology." Industrial Crops and Products 54 (March): 291-95. https://doi.org/10.1016/J.INDCROP.2014. 01.016.

Grover, P.D., S.K. Mishra, and J.S. Clancy. 1994. "Development of an Appropriate Biomass Briquetting Technology Suitable for Production and Use in Developing Countries." Energy for Sustainable Development 1 (1): 45-48.

Martynis, M., E. Sundari, and E. Sari. 2012. "Pembuatan Biobriket Dari Limbah Cangkang Kakao." Jurnal Litbang Industri $2(1): 35-41$.

Nuriana, W., and N. Anisa. 2014. "Synthesis Preliminary Studies Durian Peel Bio Briquettes as an Alternative Fuels." Energy Procedia 47: 295-302.

Pramana, A.N., and S.G. Pradana. 2010. "Pembuatan Biobriket Dari Tempurung Kemiri Sebagai Bahan Bakar Alternatif." Program Studi D3 Teknik Kimia Fakultas Teknologi Industri Institut Teknologi Sepuluh Nopember Surabaya.

Sari, E., E. Praputri, F. Permadi, O. Susanti, and R. Syafitri. 2015. "Peningkatan Kualitas Biobriket Kulit Durian Dari Segi Campuran Biomassa, Bentuk Fisik, Kuat Tekan Dan Lama Penyalaan." Simposium Nasional RAPI XIV FT UMS, ISSN 1412-9612.

Shekhar, N. 2011. "Popularization of Biomass Briquettes: A Means for Sustainable Rural Development." Asian Journal of Management Research 2 (1): 457-73. 
Shuma, R., and D.M. Madyira. 2017. "Production of Loose Biomass Briquettes from Agricultural and Forestry Residues." Procedia Manufacturing 7: 98-105.

Standard Nasional Indonesia. 2000. SNI 016235-2000: Standar Mutu Nasional Indonesia, Tentang Briket Untuk Rumah Tangga Di Indonesia.

Syamsiro, M., and H. Saptoadi. 2007. "Pembakaran Briket Biomassa Cangkang Kakao: Pengaruh Temperatur Udara Preheat." In Seminar Nasional Teknologi.
Wilasita, D.C., and R. Purwaningsih. 2014. "Pemanfaatan Limbah Tongkol Jagung Dan Tempurung Kelapa Menjadi Briket Sebagai Sumber Energi Alternatif Dengan Proses Karbonisasi Dan Non Karbonisasi. Laboratorium Pengolahan Limbah Industri, Jurusan Teknik Kimia FTI-ITS, Surabaya."

Yokoyama, S. 2008. "Buku Panduan Biomassa Asia. Panduan Untuk Produksi Dan Pemanfaaatan Biomasssa." The Japan Institute of Energy. 